Penelitian

\title{
Postmortem Changes in pH, Color, Drip Loss, and Non-Protein Nitrogen in Beef Liver and Lungs During Storage in Refrigerator
}

\section{Perubahan Postmortem pada pH, Warna, Drip Loss, dan Nitrogen Non-Protein pada Hati dan Paru Sapi Selama Penyimpanan dalam Refrigerator}

\author{
Denny Widaya Lukman ${ }^{1^{*}}$, Herwin Pisestyani', Hadri Latif', Etih Sudarnika', Mirnawati Bachrum \\ 'Division of Veterinary Public Health and Epidemiology, Faculty of Veterinary Medicine, IPB University, \\ Jalan Agatis Kampus IPB Dramaga, Bogor 16680, Indonesia \\ ${ }^{*}$ Correspondence of author: dennylukman@apps.ipb.ac.id \\ Submitted 17 October 2020, Accepted 14 November 2020
}

\begin{abstract}
Beef offal are consumed by people in some countries specifically in Asia. Beef liver and lungs are favorite food which are used as meat in traditional food. The objectives of this study was to determine the postmortem changes in $\mathrm{pH}$, color, drip loss, and non-protein nitrogen (NPN) content in beef liver and lungs during storage in refrigerator (3-4 $\left.{ }^{\circ} \mathrm{C}\right)$ until $5 \mathrm{~d}(120 \mathrm{~h})$ after slaughter. The postmortem changes in meat and offal are important to determine the quality including the freshness. The beef liver and lungs were collected from the abattoir and transported in cool box $\left(<7^{\circ} \mathrm{C}\right)$ to the laboratory within 3 hours. The samples size of beef liver and lungs were 20 for each observation time. In the laboratory the beef liver and lungs were measured directly for $\mathrm{pH}$ value, color $\left(\mathrm{L}^{*}, \mathrm{a}^{*}\right.$, and $\left.\mathrm{b}^{*}\right)$, drip loss, and NPN content at $4 \mathrm{~h}$ postmortem $(\mathrm{pm})$ and afterwards every beef liver sample was sliced into 5 pieces of $100-120 \mathrm{~g}$ and stored in chiller of $3-4^{\circ} \mathrm{C}$. The measurement of $\mathrm{pH}, \operatorname{color}\left(\mathrm{L}^{*}, \mathrm{a}^{*}\right.$, and $\mathrm{b}^{*}$ values) according to CIE LAB color space, drip loss, and NPN content were conducted at $4 \mathrm{~h}, 24 \mathrm{~h}, 48 \mathrm{~h}, 72 \mathrm{~h}, 96 \mathrm{~h}$, and $120 \mathrm{~h}$ postmortem. Data were analyzed descriptively and by comparing the $95 \%$ confidence interval of mean of each observation. The results showed that $\mathrm{pH}$, color, drip loss, and NPN content in general during the storage at refrigetor in beef lungs were higher than the values in beef liver. The $\mathrm{pH}$ of beef livers declined until $96 \mathrm{~h} \mathrm{pm}$ and until $48 \mathrm{pm}$ in beef lungs. The $\mathrm{L}^{*}$ values increased in beef liver and decreased in beef lungs. The $a^{*}$ and $b *$ values showed a slight increase in the beef livers and did not change in the beef lungs during cold storage. Drip loss and NPN in beef liver and lungs tended to increase significantly during storage. From this study it is suggested that the $\mathrm{pH}$ value of beef liver could be used to determine the freshness of beef liver, nevertheless the $\mathrm{pH}$ value of beef lungs could not be used as indicator of the freshness. The $\mathrm{pH}$ values lower than 6.15 may be considered as indicative of beef liver spoilage and the NPN content of $2.35 \mathrm{In}$ beef liver and of 1.52 in beef lungs are suggested as an indicator of spoilage is suggested as indicator of spoilage of beef liver and lungs.
\end{abstract}

Keywords: beef liver, beef lungs, color, drip loss, pH, non-protein nitrogen

\begin{abstract}
ABSTRAK
Jeroan sapi dikonsumsi oleh orang di beberapa negara khususnya di Asia. Hati dan paru sapi merupakan makanan favorit yang digunakan sebagai daging dalam beberapa makanan tradisional. Tujuan penelitian ini adalah menentukan perubahan postmortem pada $\mathrm{pH}$, warna, drip loss, dan kandungan nitrogen non-protein (NPN) pada hati dan paru sapi selama penyimpanan dalam refrigerator $\left(3-4^{\circ} \mathrm{C}\right)$ sampai 5 hari $(120 \mathrm{jam})$ setelah pemotongan. Perubahan postmortem pada daging dan jeroan penting dalam menentukan kuaitas termasuk kesegaran. Hati dan paru sapi diambil dari rumah potong hewan dan dibawa dalam boks pendingin $\left(<7^{\circ} \mathrm{C}\right)$ ke laboratorium dalam waktu 3 jam. Besaran sampel hati dan paru sapi yang digunakan dalam setiap pengamatan sebanyak 20. Saat tiba di laboratorium, hati dan paru sampel langsung diuji terhadap $\mathrm{pH}$, warna ( $\mathrm{L}^{*}, \mathrm{a}^{*}$, dan $\mathrm{b}^{*}$ ) menurut CIELAB color space, drip loss, dan kandungan NPN pada 4 jam postmortem $(\mathrm{pm})$, kemudian hati dan paru dipotong menjadi 5 potongan dengan berat sekitar 100-200 $\mathrm{g}$ dan disimpan pada refrigerator dengan suhu $3-4^{\circ} \mathrm{C}$. Pengukuran terhadap $\mathrm{pH}$, warna (nilai $\mathrm{L}^{*}$, a*, dan $\mathrm{b}^{*}$ ), drip loss, dan kandungan NPN dilakukan pada jam ke-4, ke-24, ke-48, ke-72, dan ke-120 postmortem. Data dianalisis secara deskriptif dan membandingkan nilai rata-ratanya pada selang kepercayaan 95\%. Hasil menunjukkan bahw pH, warna, drip loss, dan kandungan NPN secara umum selama penyimpanan dingin pada paru sapi lebih tinggi dari pada hati sapi. Nilai pH menurun sampaijam ke-96 pm pada hati sapi dan ke-48 pm pada paru sapi. Nilai L* meningkat pada hati sapi dan menurun
\end{abstract}


pada paru sapi. Nilai a* dan b* menunjukkan sedikit peningkatan pada hati sapid an tidak berubah pada paru sapi selama penyimpanan dingin. Drip loss dan kandungan NPN hati dan paru sapi cenderung meningkat secara nyata selama penyimpanan dingin. Dari studi ini nilai pH hati sapi disarankan dapat digunakan untuk menentukan kesegaran hati sapi sedangkan nilai pH pada paru sapi tidak dapat. dan kandungan NPN dapat digunakan untuk menentukan kesegaran hati dan paru sapi. Nilai pH di bawah 6.15 pada hati sapi dapat digunakan sebagai indicator kebusukan hati sapi, serta kandungan NPN 2.35 pada hati sapid an 1.52 pada paru sapi dapat dijadikan indikator kebusukan hati dan paru sapi.

Kata kunci: hati sapi, paru sapi, warna, drip loss, pH, nitrogen non-protein

\section{INTRODUCTION}

Beef offal is excellent source of protein for several people in some parts of the world and considered as delicacies used a traditional dishes. In Indonesia beef offal is favorite food that used as meat in some traditional food. Beef offal could be used to combat protein malnutrition and food in security in many countries (Alao et al., 2018). Offal or byproducts can be further used by humans as food or reprocessed as secondary by-products for both agricultural and industrial uses. According to Seong et al. (2014) the utilization of the meat by-products considerably depends upon a number of factors such as; culture, religion, earnings and preference.

The yield of offal has been reported to account for about $10 \%$ to $15 \%$ of the value of the live animal in developed countries, although animal by-products account for about two-third of the animal after slaughter (Alao et al., 2017). Edible offal constitute about $20-30 \%$ of live weight of cattle (Khalil et al., 2018). The range of yields of beef liver and lungs are $1.0-4.5 \%$ of live weight and $0.4-0.8 \%$ of live weight, respectively (Ockerman et al., 2017). Offal cuts are good sources of protein, and notably very valuable for its nutrition (van Heerden \& Morey, 2014). Liver is high in vitamin $A$, iron, zinc, vitamin B, vitamin C, vitamin D, copper, and fatty acids (Khalil et al., 2018) and lungs contain high levels of protein and bioavailable iron (Jayawardena et al., 2018). However, edible offal are highly perishable because of the high content of nutrients for microbial growth (Custódio et al., 2016).

The $\mathrm{pH}$ value, color, and drip loss are used for determination of quality of meat and meat products including offal. However there is still few studies on postmortem changes in beef lungs due to $\mathrm{pH}$, color, and drip loss. The studies in beef liver related to microbiology (Shelef, 1975; Devatkal \& Mendiratta, 2006; Hemmat et al., 2013; Alexanyan et al., 2014), nutrition (Li et al., 2014; Kakimov et al., 2018; Biel et al., 2019), and chemical changes (Custódio et al., 2016; Alexanyan et al. ,2014) are many recorded. The studies on $\mathrm{pH}$ of beef liver had been reported by Shelef (1975), Hanna et al. (1982), Hernández-Herrero et al. (1999), and Hemmat et al. (2013). Drip loss in beef liver was reported by Strange(1984).

The CIELAB color space is the most frequently used system to specify food colors. It is a three dimensional Cartesian space with three mutually perpendicular color coordinates: $L^{*}$, the correlate of perceptual lightness; $a^{*}$ that represents the red $\left(a^{*}>0\right)$ green $\left(a^{*}<0\right)$ axis and $b^{*}$ that represents the yellow $\left(b^{*}>0\right)$ blue $\left(b^{*}<0\right)$ axis (Hernández et al., 2016).

Non-protein nitrogen (NPN) compounds in meat include nucleotides, peptides, creatine, creatine phosphate, urea, inosine monophosphate, nicotinamide-adenine dinucleotide (Keeton et al., 2014). Meat is composed of approximately $1.5 \%$ nonprotein nitrogen compounds (Honikel, 2009: Keeton et al., 2014). NPN in non-heated pork was $(5 \pm 0.41) \mathrm{g} / \mathrm{kg}$, $(2.72 \pm 0.41) \mathrm{g} / \mathrm{kg}$ and $(2.89 \pm 0.43) \mathrm{g} / \mathrm{kg}$ nitrogen for non-cured, 10\%-brine-cured and 20\%-brine-cured pork, respectively (Paulsen et al., 2006). The total volatile base nitrogen (TVB-N) parameter is used as a food freshness indicator, since volatile nitrogenbased compounds are the product of the degradation of protein and non-protein nitrogen compounds, such as trimethylamine (TMA) and ammonia, which are mainly associated with the growth of spoilage bacteria (Conte-Junior et al., 2020).

The study was conducted to determine the postmortem changes during the cool storage in order to determine the freshness of beef liver and lungs since there are still lack parameters for determination of freshness of beef offal besides the organoleptic test and microbiological examination. The aims of this study was to determine the postmortem changes on $\mathrm{pH}$, color, drip loss, and NPN content in beef liver and lungs during storage in refrigerator $\left(3-4^{\circ} \mathrm{C}\right)$ until $5 \mathrm{~d}(12 \mathrm{O} \mathrm{h})$ after slaughter.

\section{MATERIALS AND METHOD}

\section{Samples}

The beef liver and lung samples were collected 
from the abattoir and transported in cool box ( $<7$ ${ }^{\circ} \mathrm{C}$ ) to the laboratory within 3 hours.

\section{Measurement of pH, Color, Drip Loss, and NPN}

The samples size were 20 for each observation time. In the laboratory the beef liver and lung samples were measured directly on $\mathrm{pH}$ value, color ( $\mathrm{L}^{*}$, $a^{*}$, and $\left.b^{*}\right)$, drip loss, and NPN content at $4 \mathrm{~h}$ postmortem (pm) and afterwards every beef liver and lungs sample was sliced into 5 pieces of 100-120 g, put into sterile plastic bag, and hung in refrigerator with temperature of $3-4{ }^{\circ} \mathrm{C}$. The measurement of $\mathrm{pH}$, color ( $\mathrm{L}^{*}, \mathrm{a}^{*}$, and $\mathrm{b}^{*}$ values), drip loss, and NPN content were conducted at $4 \mathrm{~h}, 24 \mathrm{~h}, 48 \mathrm{~h}, 72 \mathrm{~h}, 96$ $\mathrm{h}$, and $120 \mathrm{~h}$ postmortem (pm).

The $\mathrm{pH}$ value in beef liver was measured by using a digital pH meter (WTW, Germany) by insert the electrode into 3 different places in liver and the mean value of three measurements were calculated for 1 sample. Beef lungs were homogenized first using ultra-turrax homogenizer (IKA Ultra-TurraxSystem T25, Gemany) and measured for the $\mathrm{pH}$ with 3 times measurement for each sample. The of $L^{*}$, $a^{*}$, and $b^{*}$ were determined by using by chroma meter (Minolta CR 300, Japan) which was applied to measure on 3 different places on the surface of beef liver and the mean value of $L^{*}, a^{*}$, and $b^{*}$ was determined.

Drip loss was measured using the method of Honikel (1987). The sample was weighed approximately $100 \mathrm{~g}$ and put into a plastic bag and hung using a hook in chillerwith thetemperature of $3-4^{\circ} \mathrm{C}$. After $48 \mathrm{~h}$ the sample was taken out from the plastic bag, carefully taped using paper towels, and subsequently weighed. The drip loss was expressed as a percentage of the initial weight.

NPN content was measured by using the method in the Collection of Official Methods under Article 64 of the German Federal Foods Act; Band I (L), L 06.00-7 2014-08, Determination of Protein Content in Meat and Meat Products; Titration Method according to Kjeldahl Reference Method. Five grams of sample was put into centrifuge glass and added with $50 \mathrm{~mL}$ of $20 \%$ trichloroacetic acid. The sample was homogenized with ultra-turrax homogenizer (IKA Ultra-Turrax-System T25, Gemany) and let stand for $5 \mathrm{~min}$, then centrifuged at 5000 rpm for 20 min, and the supernatant was collected.

The supernatant was transferred to distillation flask, and added with Kjeldahl tablets (Merck No 153481000 ), glass granules, $20 \mathrm{~mL}$ of $98 \%$ sulfuric acid (Merck No 100748), and $10 \mathrm{~mL}$ of $35 \%$ hydrogen peroxide (Merck No 108600). The distillation flask was heated at $400 \pm 10{ }^{\circ} \mathrm{C}$ for $1-2 \mathrm{~h}$ until the solution was clear, and let it cool and then added with $30 \mathrm{~mL}$ aquadest. The solution in distillation flask was adjusted to $100 \mathrm{~mL}$ with $0.1 \mathrm{~N}$ sodium hydroxide (Merck No 109141) and subsequently digested in Kjeldahl distillation apparatus (Gerhardt, Germany) and boiled with boric acid 9Merck No 1001651000). The distillation was stopped when the volume of boric acid reached $200 \mathrm{ml}$. Then the distillate was titrated with $0.1 \mathrm{~N}$ hydrochloric acid. The NPN content was calculated with the following equation:

NPN $(\mathrm{g} / \mathrm{kg})=($ volume of titration $\times 1.4007) /$ weight of sample

\section{Data Analysis}

Data were analyzed descriptively to describe the changes on $\mathrm{pH}$, color, and drip loss during chilling. Furthermore, the $95 \%$ confidence interval of mean of each observation were compared in each response variables.

\section{RESULTS}

\section{pH Value}

The $\mathrm{pH}$ values of fresh beef lungs were higher than beef liver. The $\mathrm{pH}$ of beef liver declined from 6.25 at $4 \mathrm{~h} \mathrm{pm}$ to 6.15 at $96 \mathrm{~h} \mathrm{pm}$ and then increased, while the lungs decreased from 6.62 at $4 \mathrm{~h} \mathrm{pm}$ to 6.44 at $48 \mathrm{~h} \mathrm{pm}$ and afterwards constant. At $120 \mathrm{~h} \mathrm{pm}$ the off odors of beef liver and lungs had been occurred (Table 1 and 2). There was a significant difference on $\mathrm{pH}$ value among the time of observation at 4, 24 and 72, $96 \mathrm{~h}$ postmortem in beef liver. As for beef lungs, there was a significant decrease in $\mathrm{pH}$ at 4, 24 and $48 \mathrm{~h}$ postmortem, but subsequently there was no significant difference up to $120 \mathrm{~h}$ postmortem (Table 3 and 4).

\section{Color}

The color $\left(L^{*}, a^{*}\right.$, and $\left.b^{*}\right)$ values of beef lungs showed higher than the beef liver. During storage the $L^{*}$ values of beef liver generally increased from 23.40 at $4 \mathrm{~h}$ pm to 25.26 at $120 \mathrm{~h} \mathrm{pm}$, whereas the a* and $b^{*}$ values increased until $96 \mathrm{~h}$ pm and then decreased. For beef livers, there was no significant increase in $L^{*}$ values at 4 to $72 \mathrm{~h} \mathrm{pm}$, and it was only significantly different at 96 to $120 \mathrm{~h} \mathrm{pm}$. The a* value had a significant difference between $4 \mathrm{~h}$ pm and $96 \mathrm{~h} \mathrm{pm}$, while the value of $\mathrm{b}$ increased significantly at 4 to $24 \mathrm{~h} \mathrm{pm}$, and then there was no significant change up to $120 \mathrm{~h} \mathrm{pm}$. 
Table 1 Mean and standard deviation of pH, color, drip loss, and NPN content in beef liver during storage

\begin{tabular}{lcccccc}
\hline \multirow{2}{*}{$\begin{array}{l}\text { Storage } \\
(\mathrm{h} \mathrm{pm})\end{array}$} & $\begin{array}{c}\mathrm{pH} \text { value } \\
(\mathrm{n}=20)\end{array}$ & \multicolumn{3}{c}{ Color $(\mathrm{n}=20)$} & $\begin{array}{c}\text { Drip loss }(\%) \\
(\mathrm{n}=20)\end{array}$ & $\begin{array}{c}\mathrm{NPN} \\
(\mathrm{g} / \mathrm{kg})\end{array}$ \\
\hline \hline 4 & $6.25 \pm 0.09$ & $23.40 \pm 0.90$ & $15.74 \pm 1.15$ & $5.49 \pm 0.83$ & $1.34 \pm 0.39$ & $1.97 \pm 0.24$ \\
24 & $6.21 \pm 0.03$ & $23.25 \pm 1.46$ & $15.90 \pm 1.56$ & $6.42 \pm 1.13$ & $2.27 \pm 0.86$ & $2.12 \pm 0.20$ \\
48 & $6.20 \pm 0.06$ & $24.03 \pm 1.58$ & $16.52 \pm 0.97$ & $6.57 \pm 0.97$ & $2.71 \pm 0.91$ & $2.18 \pm 0.21$ \\
72 & $6.18 \pm 0.05$ & $24.03 \pm 1.14$ & $16.53 \pm 0.94$ & $7.03 \pm 0.78$ & $3.24 \pm 1.16$ & $2.26 \pm 0.18$ \\
$96^{\mathrm{s}}$ & $6.15 \pm 0.07$ & $24.93 \pm 2.01$ & $17.28 \pm 1.02$ & $6.85 \pm 1.20$ & $3.46 \pm 1.37$ & $2.35 \pm 0.19$ \\
$120^{\mathrm{s}}$ & $6.19 \pm 0.07$ & $25.26 \pm 2.32$ & $16.46 \pm 1.68$ & $6.48 \pm 0.93$ & $4.06 \pm 1.41$ & $2.49 \pm 0.21$ \\
\hline
\end{tabular}

${ }^{\mathrm{s}}$ the samples were sensorically spoilage.

Table 2 Mean and standard deviation of $\mathrm{pH}$, color, drip loss, and NPN content in beef lungs during storage

\begin{tabular}{lcccccc}
\hline \multirow{2}{*}{$\begin{array}{l}\text { Storage } \\
(\mathrm{h} \mathrm{pm})\end{array}$} & $\begin{array}{c}\mathrm{pH} \text { value } \\
(\mathrm{n}=20)\end{array}$ & \multicolumn{3}{c}{ Color $(\mathrm{n}=20)$} & $\begin{array}{c}\text { Drip loss }(\%) \\
(\mathrm{n}=20)\end{array}$ & $\begin{array}{c}\text { NPN } \\
(\mathrm{g} / \mathrm{kg})\end{array}$ \\
\hline \hline 4 & $6.62 \pm 0.09$ & $39.19 \pm 2.67$ & $31.48 \pm 1.85$ & $13.55 \pm 1.79$ & $1.42 \pm 0.31$ & $1.21 \pm 0.15$ \\
24 & $6.54 \pm 0.03$ & $38.67 \pm 2.55$ & $31.67 \pm 2.65$ & $13.73 \pm 1.36$ & $1.50 \pm 0.52$ & $1.28 \pm 0.15$ \\
48 & $6.44 \pm 0.06$ & $40.47 \pm 3.11$ & $31.08 \pm 2.72$ & $14.09 \pm 1.39$ & $1.28 \pm 0.33$ & $1.37 \pm 0.14$ \\
72 & $6.44 \pm 0.05$ & $40.12 \pm 3.83$ & $31.76 \pm 2.29$ & $14.73 \pm 1.80$ & $1.48 \pm 0.49$ & $1.44 \pm 0.15$ \\
$96^{5}$ & $6.44 \pm 0.07$ & $37.66 \pm 2.09$ & $31.08 \pm 2.46$ & $13.91 \pm 1.67$ & $1.52 \pm 0.50$ & $1.52 \pm 0.14$ \\
$120^{5}$ & $6.44 \pm 0.07$ & $36.35 \pm 3.17$ & $31.76 \pm 2.64$ & $14.35 \pm 1.87$ & $1.55 \pm 0.38$ & $1.52 \pm 0.16$ \\
\hline
\end{tabular}

${ }^{\mathrm{s}}$ the samples were sensorically spoilage.

The $L^{*}$ values of lungs appeared to fluctuate, but not statistically significant, and decreased significantly at 96 and $120 \mathrm{~h}$ pm. While a* and b* there was no significant difference until the last observation (Tables 3 and 4). Drip Loss

The drip loss tended to increase overtime. The drip loss in liver, increase significantly from $1.34 \%$ at $4 \mathrm{~h} \mathrm{pm}$ to $4.06 \%$ at $120 \mathrm{~h} \mathrm{pm}$. While for the drip loss in lung, there was no significant difference until the last observation (Table 3 and 4). The drip loss in liver during storage was a little bit higher than in lungs.

\section{Non-Protein Nitrogen Content}

The non-protein nitrogen(NPN) content increased gradually during storage from $1.97 \mathrm{~g} / \mathrm{kg}$ at $4 \mathrm{~h}$ pm to
$4.06 \mathrm{~g} / \mathrm{kg}$ at $120 \mathrm{~h} \mathrm{pm}$ in liver and from $1.21 \mathrm{~g} / \mathrm{kg}$ at 4 $\mathrm{h}$ pm to $1.52 \mathrm{~g} / \mathrm{kg}$ at $120 \mathrm{~h} \mathrm{pm}$ in lungs (Table 1, 2, 3, 4). The NPN content in liver was higher than in lungs.

\section{DISCUSSION}

This study found the $\mathrm{pH}$ of beef liver and lungs at $4 \mathrm{~h} \mathrm{pm}$ of 6.25 and 6.62, respectively. The $\mathrm{pH}$ of beef liver was lower than the lungs. The result was similar to the study of Seong et al. (2014) that showed the $\mathrm{pH}$ of 6.23 in beef liver and 6.60 in lungs. In pig offal, Tomović et al. (2016) found also the pH of liver (5.966.21) was lower than the lungs (6.80-6.91). The $\mathrm{pH}$ of beef liver and lungs was a little bit lower than $\mathrm{pH}$ of meat that has around 7.2 after slaughter (England et al., 2017; Matarneh et al., 2017). 
Table 3 Mean and 95\% confidence interval of $\mathrm{pH}$, color, drip loss, and NPN content in beef liver during storage

\begin{tabular}{|c|c|c|c|c|c|c|c|c|c|c|c|c|c|c|c|c|c|c|}
\hline \multirow{2}{*}{ h pm } & \multicolumn{3}{|c|}{$\begin{array}{c}\mathrm{pH} \text { (Confidence Interval } \\
95 \%)\end{array}$} & \multicolumn{3}{|c|}{$\begin{array}{c}\mathrm{L} \text { (Confidence Interval } \\
95 \%)\end{array}$} & \multicolumn{3}{|c|}{ a (Confidence Interval 95\%) } & \multicolumn{3}{|c|}{$\begin{array}{c}\text { b (Confidence Interval } \\
95 \%)\end{array}$} & \multicolumn{3}{|c|}{$\begin{array}{c}\text { Drip loss (Confidence } \\
\text { Interval 95\%) }\end{array}$} & \multicolumn{3}{|c|}{$\begin{array}{l}\text { NPN (Confidence } \\
\text { Interval 95\%) }\end{array}$} \\
\hline & Mean & $\begin{array}{l}\text { Lower } \\
\text { Limit }\end{array}$ & $\begin{array}{l}\text { Upper } \\
\text { Limit }\end{array}$ & Mean & $\begin{array}{l}\text { Lower } \\
\text { Limit }\end{array}$ & $\begin{array}{l}\text { Upper } \\
\text { Limit }\end{array}$ & Mean & $\begin{array}{l}\text { Lower } \\
\text { Limit }\end{array}$ & $\begin{array}{l}\text { Upper } \\
\text { Limit }\end{array}$ & Mean & $\begin{array}{l}\text { Lower } \\
\text { Limit }\end{array}$ & $\begin{array}{l}\text { Upper } \\
\text { Limit }\end{array}$ & Mean & $\begin{array}{l}\text { Lower } \\
\text { Limit }\end{array}$ & $\begin{array}{l}\text { Upper } \\
\text { Limit }\end{array}$ & Mean & $\begin{array}{l}\text { Lower } \\
\text { Limit }\end{array}$ & $\begin{array}{l}\text { Upper } \\
\text { Limit }\end{array}$ \\
\hline 4 & $6.25^{b}$ & 6.21 & 6.29 & $23.40^{\mathrm{b}}$ & 22.98 & 23.82 & $15.74^{a}$ & 15.20 & 16.28 & $5.49^{a}$ & 5.10 & 5.88 & $1.34^{a}$ & 1.16 & 1.52 & $1.97^{\mathrm{a}}$ & 1.86 & 2.08 \\
\hline 24 & $6.21^{b}$ & 6.20 & 6.22 & $23.25^{\mathrm{a}}$ & 22.57 & 23.93 & $15.90^{a}$ & 15.17 & 16.63 & $6.42^{\mathrm{b}}$ & 5.89 & 6.95 & $2.27^{\mathrm{b}}$ & 1.87 & 2.67 & $2.12^{\mathrm{ab}}$ & 2.03 & 2.21 \\
\hline 48 & $6.20^{\mathrm{ab}}$ & 6.17 & 6.23 & $24.03^{b c}$ & 23.29 & 24.77 & $16.52^{\mathrm{ab}}$ & 16.07 & 16.97 & $6.57^{b}$ & 6.12 & 7.02 & $2.71 \mathrm{bc}$ & 2.28 & 3.14 & $2.18^{\mathrm{bc}}$ & 2.08 & 2.28 \\
\hline 72 & $6.18^{\mathrm{a}}$ & 6.16 & 6.20 & $24.03^{\mathrm{bc}}$ & 23.50 & 24.56 & $16.53^{\mathrm{ab}}$ & 16.09 & 16.97 & $7.03^{b}$ & 6.66 & 7.40 & $3.24^{\mathrm{cd}}$ & 2.70 & 3.78 & $2.26^{\mathrm{bc}}$ & 2.18 & 2.34 \\
\hline 96 & $6.15^{a}$ & 6.12 & 6.18 & $24.93^{c}$ & 23.99 & 25.87 & $17.28^{\mathrm{b}}$ & 16.80 & 17.76 & $6.85^{\mathrm{b}}$ & 6.29 & 7.41 & $3.46^{\mathrm{cd}}$ & 2.82 & 4.10 & $2.35^{\mathrm{cd}}$ & 2.26 & 2.44 \\
\hline 120 & $6.19^{a b}$ & 6.16 & 6.22 & $25.26^{c}$ & 24.17 & 26.35 & $16.46^{\mathrm{ab}}$ & 15.67 & 17.25 & $6.48^{\mathrm{b}}$ & 6.04 & 6.92 & $4.06^{d}$ & 3.40 & 4.72 & $2.49^{d}$ & 2.39 & 2.59 \\
\hline
\end{tabular}

Superscript on mean value: different letters in the same column show significant differences at the $95 \%$ confidence level.

Table 4 Mean and standard deviation of pH, color, drip loss, and NPN content in beef lungs during storage

\begin{tabular}{|c|c|c|c|c|c|c|c|c|c|c|c|c|c|c|c|c|c|c|}
\hline \multirow{2}{*}{$\begin{array}{c}\mathrm{h} \\
\mathrm{pm}\end{array}$} & \multicolumn{3}{|c|}{$\begin{array}{c}\mathrm{pH} \text { (Confidence Interval } \\
95 \%)\end{array}$} & \multicolumn{3}{|c|}{$\begin{array}{c}\text { L (Confidence Interval } \\
95 \%) \\
\end{array}$} & \multicolumn{3}{|c|}{$\begin{array}{c}\text { a (Confidence Interval } \\
95 \%) \\
\end{array}$} & \multicolumn{3}{|c|}{$\begin{array}{c}\text { b (Confidence Interval } \\
95 \%) \\
\end{array}$} & \multicolumn{3}{|c|}{$\begin{array}{l}\text { Drip loss (Confidence } \\
\text { Interval 95\%) }\end{array}$} & \multicolumn{3}{|c|}{$\begin{array}{l}\text { NPN (Confidence } \\
\text { Interval 95\%) }\end{array}$} \\
\hline & Mean & $\begin{array}{l}\text { Lower } \\
\text { Limit }\end{array}$ & $\begin{array}{l}\text { Upper } \\
\text { Limit }\end{array}$ & Mean & $\begin{array}{l}\text { Lower } \\
\text { Limit }\end{array}$ & $\begin{array}{l}\text { Upper } \\
\text { Limit }\end{array}$ & Mean & $\begin{array}{l}\text { Lower } \\
\text { Limit }\end{array}$ & $\begin{array}{l}\text { Upper } \\
\text { Limit }\end{array}$ & Mean & $\begin{array}{l}\text { Lower } \\
\text { Limit }\end{array}$ & $\begin{array}{l}\text { Upper } \\
\text { Limit }\end{array}$ & Mean & $\begin{array}{l}\text { Lower } \\
\text { Limit }\end{array}$ & $\begin{array}{l}\text { Upper } \\
\text { Limit }\end{array}$ & Mean & $\begin{array}{l}\text { Lower } \\
\text { Limit }\end{array}$ & $\begin{array}{l}\text { Upper } \\
\text { Limit }\end{array}$ \\
\hline 4 & $6.62^{c}$ & 6.58 & 6.66 & $39.2^{b c}$ & 37.94 & 40.44 & $31.5^{a}$ & 30.61 & 32.35 & $13.6^{a}$ & 12.71 & 14.39 & $1.42^{a}$ & 1.27 & 1.57 & $1.21^{\prime \prime}$ & 1.14 & 1.28 \\
\hline 24 & $6.54^{b}$ & 6.53 & 6.55 & $38.7^{\mathrm{abc}}$ & 37.48 & 39.86 & $31.7^{\mathrm{a}}$ & 30.43 & 32.91 & $13.7^{a}$ & 13.09 & $14 \cdot 37$ & $1.5^{\mathrm{a}}$ & 1.26 & 1.74 & $1.28^{\mathrm{ab}}$ & 1.21 & 1.35 \\
\hline 48 & $6.44^{a}$ & 6.41 & 6.47 & $40.5^{c}$ & 39.01 & 41.93 & $31.1^{\mathrm{a}}$ & 29.81 & 32.35 & $14.1^{\mathrm{a}}$ & 13.44 & 14.74 & $1.28^{\mathrm{a}}$ & 1.13 & 1.43 & $1.37^{\mathrm{bc}}$ & 1.30 & 1.44 \\
\hline 72 & $6.44^{\mathrm{a}}$ & 6.42 & 6.46 & $40.1^{b c}$ & 38.33 & 41.91 & $31.8^{a}$ & 30.69 & 32.83 & $14 \cdot 7^{\mathrm{a}}$ & 13.89 & 15.57 & $1.48^{\mathrm{a}}$ & 1.25 & 1.71 & $1.44^{\mathrm{cd}}$ & 1.37 & 1.51 \\
\hline 96 & $6.44^{\mathrm{a}}$ & 6.41 & 6.47 & $37.7^{\mathrm{ab}}$ & 36.68 & 38.64 & $31.1^{\mathrm{a}}$ & 29.93 & 32.23 & $13 \cdot 9^{a}$ & 13.13 & 14.69 & $1.52^{a}$ & 1.29 & 1.75 & $1.52^{d}$ & 1.45 & 1.59 \\
\hline 120 & $6.44^{\mathrm{a}}$ & 6.41 & 6.47 & $36.4^{a}$ & 34.87 & 37.83 & $31.8^{\mathrm{a}}$ & 30.52 & 33.00 & $14.4^{\mathrm{a}}$ & 13.47 & 15.23 & $1.55^{\mathrm{a}}$ & 1.37 & 1.73 & $1.52^{\mathrm{d}}$ & 1.45 & 1.59 \\
\hline
\end{tabular}

Superscript on mean value: different letters in the same column show significant differences at the $95 \%$ confidence level. 
Decrease of $\mathrm{pH}$ in liver and lungs is related to lactic acid that increases during storage after slaughter (Gill \& DeLacy, 1982; Hernández-Herrero et al., 1999). During the storage of liver and lungs, the glycogen concentration declined and the lactic acid concentration increased with time. The ammonia concentration began to increase markedly after 4 days of storage. Accumulation of lactic acid and ammonia would have opposite effects upon the $\mathrm{pH}$, but the $\mathrm{pH}$ declined throughout the period of storage (Gill \& DeLacy, 1982). The presence of amines at high levels could be associated with spoilage and microbial growth. The presence of these amines at high levels in liver could be associated with spoilage and microbial growth (Custódio et al., 2016). The $\mathrm{pH}$ value is a valuable indicator to estimate the spoilage status of beef liver stored under aerobic condition (Shelef, 1975; Hanna et al., 1982; Hernández-Herrero et al., 1999). Shelef (1975) suggested a pH of 6.1 as a reliable indicator of beef liver spoilage, while Hanna et al. (1982) and Hernández-Herrero et al. (1999) suggested a pH of 6.0 and 6.15 , respectively. There were not any studies on the $\mathrm{pH}$ of beef lungs conducted. The $\mathrm{pH}$ of beef lungs in this study was not different among the observation at $48,72,96$, and $120 \mathrm{~h} \mathrm{pm}$, therefore the $\mathrm{pH}$ of beef lungs could not used as indicator of freshness.

Meat color can be objectively described by L*, $a *$, and $b *$ values (Hernández et al., 2016). Consumers' perception on meat quality is directly related to visual appearance particularly color (Alao et al., 2018). This study showed the slight increase of $L^{*}$, $a^{*}$, and $b^{*}$ values during storage. Hernández et al. (2016) recorded increase of $L^{*}$ values, slight decrease of $a^{*}$ values, and relatively constant of $b^{*}$ values in beef meat during storage at 1,4 , and 7 day.

Drip loss in this study increased significantly during the storage until $120 \mathrm{~h} \mathrm{pm}$. This result compared favorably with the results of Strange (1987). The drip loss in beef liver was higher than in beef lungs since the $\mathrm{pH}$ of beef liver was lower than beeflungs. The low $\mathrm{pH}$ value has low water binding capacity which causes high drip loss (Warner, 2017). Losses of water from meat can occur via evaporation, gravitational drip, thawing, or cooking, and low water holding capacity (Apple \& Yancey, 2013). Measurement of drip loss is to determine the water holding capacity of meat (Apple \& Yancey, 2013; Torres Filho et al., 2017; Warner, 2017).

Drip from liver and from muscle may differ because of differences in structure and function of striated muscle and liver. Liver has much larger extracellular spaces; about $22 \%$ of the liver volume consists of sinusoids or capillary bed and large blood vessels. Liver and other edible offal contain a large portion of the residual blood in the carcass. Liver drip consisted of $40 \%$ blood with the rest of the fluids released by the cells during cell death and damage to the cell membranes, in contrast to muscle drip which was almost entirely sarcoplasmic proteins and water (Strange, 1987).

During storage the NPN content becomes higher because of the degradation of protein in meat and offal (England et al., 2017). According to Tikk (2008), upon slaughter of the animal, the protein synthesis stops; however, the activity of proteolytic enzymes continues as long as the prerequisites for enzymatic activity are present. Factors of importance are suitable $\mathrm{pH}$, temperature, substrate availability and presence of specific ions or inhibitors. Triki et al. (2018) describe that proteolysis forms peptides, dipeptides, and free amino acids which are categorized as non-protein nitrogen. The NPN is then used by microorganisms for their growth which then causes the spoilage even during refrigerated storage. Min et al. (2007) and ConteJunior et al. (2020) stated that the total volatile basic nitrogen (TVB-N) parameter is utilized as a meat freshness indicator, since volatile nitrogenbased compounds are the product of the degradation of protein and non-protein nitrogen compounds, such as trimethylamine (TMA) and ammonia, which are mainly associated with the growth of spoilage bacteria. There are no studies on measurement of NPN content in beef liver and lungs, therefore the NPN content of 2.35 in beef liver and of 1.52 in beef lungs are suggested as an indicator of the spoilage of beef liver and lungs.

The $\mathrm{pH}$ value of beef liver and lungs declined, nevertheless The $L^{*}$ values increased in beef liver and decreased in beef lungs. The $a^{*}$ and $b *$ values showed a slight increase in the beef livers and did not change in the beef lungs. Drip loss and NPN content increased after slaughtering. From this study it is suggested that the $\mathrm{pH}$ value can be used to determine the freshness of beef liver. The $\mathrm{pH}$ values lower than 6.15 may be considered as indicative of beef liver spoilage as stated by the previous study, nevertheless the $\mathrm{pH}$ value of beef lungs may not be used to determine the freshness. Furthermore, the NPN content of 2.35 in beef liver and of 1.52 in beef lungs are suggested as an indicator of spoilage is suggested as indicator of spoilage of beef liver and lungs. 
"All authors declare that there are no conflicts of interest".

\section{REFERENCES}

Alao BO, Falowo AB, Chulayo A, Muchenje V. 2017. The potential of animal by-products in food systems: production, prospects and challenges. Sustainability. 9:1089. https://doi.org/10.3390/su 9071089

Alao BO, Falowo AB, Chulayo A, Muchenje V. 2018. Consumers' preference and factors influencing offal consumption in Amathole District Eastern Cape, South Africa. Sustainability. 10:3323. https://doi.org/10.339o/su1009 3323

Alexanyan IJ, Nugmanov A-X, Titova LM, Nikulina MA. 2014. Influence of an antimicrobic alginate covering on a period of storage and quality indicators of the cooled beef liver. Life Sci J. 11(11s).

Apple JK, Yancey JWS. 2013. Water-Holding Capacity of Meat. In Kerth CR (Ed.), The Science of Meat Quality. West Sussex (UK): John Wiley.

Biel W, Czerniawska-Piatkowska E, Kowalczyk A. 2019. Offal chemical composition from veal, beef, and lamb maintained in organic production systems. Animals. 9:489. https:// doi.org/10. 3390/ anigo80489

Conte-Junior CA, Monteiro MLG, Patrícia R, Mársico ET, Lopes MM, 3, Alvares TS, Mano SB. 2020. The effect of different packaging systems on the shelf life of refrigerated ground beef. Foods. 9:495. https://doi.org/doi:10.3390/foods9040495

Custódio FB, Theodoro KH, Gloria MBA. 2016. Bioactive amines in fresh beef liver and influence of refrigerated storage and pan-roasting. Food Control. 60:151e157.http://dx.doi.org/10.1016/j.foodcont.20 15.07.037

Devatkal S, Mendiratta SK. 2006. Evaluation of shelf life and spoilage pattem of aerobically stored buffalo liver. J Muscle Foods. 18:276-284.

England EM, Matarneh SK, Scheffler TL, Gerrard DE. 2017. Perimortal Muscle Metabolism and its Effects on Meat Quality. In Purslow PP (ed.), New Aspects of Meat Quality from Genes to Ethics. Duxford (UK): Woodhead Publishing. http://dx.doi.org/10.1016/B978-0-08-1005934.00004-7

Gill CO, DeLacy KM. 1982. Microbial spoilage of whole sheep livers. Appl Environ Microbiol. 43(6):1262-1266. https://doi.org/10.1128/aem. 43.6.1262-1266.1982

Hanna MO, Smith GC, Savel JW, McKeith FK, VanderzantC. 1982. Effects of packaging methods on the microbial flora of livers and kidneys from beef and pork. J Food Prot. 45(1):63-73. https://doi.org/10.4315/0362-028x-45.1.63

Hemmat MI HM, Reham AA, Omima AS, El Shafay MS. 2013. Quality of beef and edible offal at abattoir level. BVMJ. 25(2):254-263.

Hernández B, Sáenz C, Alberdi C, Diñeiro JM. 2016. CIELAB color coordinates versus relative proportions of myoglobin redox forms in the description of fresh meat appearance. J Food Sci Technol.53(12):4159-4167.https://doi.org/10.1007/s13 197-016-2394-6

Hernández-Herrero $M M$, Roig-Sagués $A X$, López-Sabater El, Rodríguez-Jerez JJ, Mora-Ventura MT. 1999. Influence of storage temperature on the quality of beef liver; $\mathrm{pH}$ as a reliable indicator of beef liver spoilage. J Sci Food Agric.79:2035-2039.https://doi.org/10.1002/(SICl) 1097-0010(199911)79:14\%3C2035::AID-JSFA481\% 3E3.0.CO;2-I

Honikel KO. 1987. The water binding of meat. Fleischwirtsch. 67(9):1098-1102.

Honikel KO. 2009. Composition and Calories. In Nollet LML, Toldrá F (eds.), Handbook of Muscle Foods Analysis. Boca Raton (US): CRC Pr.

Jayawardena SR, Morton JD, Brennan CS, Bekhit AEA. 2018. Utilisation of beef lung protein powder as a functional ingredient to enhance protein and iron content of fresh pasta. Int J Food Sci Technol. 2018. https://doi.org/doi:10.1111/ijfs.13927

Kakimov A, Suychinov A, Tsoy A, Mustambayev N, Ibragimov N, Kuderinova1 N, Mirasheva G, Yessimbekov Z. 2018. Nutritive and biological value of liver and blood of various slaughtered animals. JPRI. 22(3):1-5.

Keeton JT, Ellerbeck SM, MT González MTN. 2014. Chemical Composition. In Dikeman M, Devine C (Eds.), Encyclopedia of Meat Sciences. $2^{\text {nd }}$ Ed. Vol 1. San Diego (US): Academic Pr

Khalil AM, Mousa MM, El-Bahy EF. 2018. Sanitary condition of some raw edible beef offal. AJVS. Vol.59(2):165-172.https://doi.org/10. 5455/ajvs.234694

Li R-R, Yu Q-L, Han L, Cao H. 2014. Nutritional characteristics and active components in liver from wagyu ×qinchuan cattle. Korean J Food Sci An. 34 (2):214-220.http://dx.doi.org/10.5851/kosfa. 2014.34.2.214

Matarneh SK, England EM, Scheffler TL, Gerrard DE. 2017. The Conversion of Muscle to Meat. In Toldrá $F$ (ed.), Lawrie's Meat Science. Duxford (UK):Woodhead Publishing. http://dx.doi.org/ 10.1016/B978-0-08-100694-8.00005-4 
Min JS, Lee SO, Jang A, Jo C, Park CS, Lee M. 2007. Relationship between the concentration of biogenic amines and volatile basic nitrogen in fresh beef, pork, and chicken meat. Asian-Aust J Anim Sci. 20 (8):1278 - 1284

Ockerman HW, Basu L, Toldrá F. 2017. Edible Byproducts. In Toldrá $F$ (ed.), Lawrie's Meat Science. Duxford, United Kingdom: Woodhead Publishing. http://dx.doi.org/10.1016/ B978-0-08100694-8.00005-4

Paulsen P, Hagen U, Bauer F. 2006. Changes in biogenic amine contents, non-protein nitrogen and crude protein during curing and thermal processing of $M$. longissimus, pars lumborum of pork. Eur Food Res Technol. 223:603-608. https://doi.org/10.1007/so 0217-005-0240-6

Seong PN, Kang GH, Park KM, Cho SH, Kang SM, Park BY, Moon SS, Ba HV. 2014. Characterization of Hanwoo Bovine by-products by means of yield, physicochemical and nutritional compositions. Korean J Food Sci An. 34(4):434 447. http://dx.doi.org/10.5851/kosfa.2014.34.4.434

Shelef J. 1975. Microbial spoilage of fresh refrigerated beef liver. J Appl Bacteriol. 39(3):273-280. https://doi.org/10.1111/j.1365-2672.1975.tbo 0572.x

Strange ED. 1987. Quantitation and characterization of drip from frozen-thawed refrigerated pork liver. J Food Sci. 52(4):910-915. https://doi.org/ 10.1111/j.1365-2621.1987.tb14240.x
Tikk M. 2008. Peptidesand Ribonucleotides in Fresh Meat as a Function of Aging in Relation to Sensory Attributes of Pork. DoctoralThesis. Uppsala, Sweden: Swedish University of Agricultural Sciences.

Tomović $\mathrm{V}$, Žlender $B$, Jokanović $M$, Tomović $M$, Šojić B, Škaljac S, Kevrešan Z, Tasić T, Ikonić P, Okanović D. 2016. Physical and chemical characteristics of edible offal from free-range reared swallow-belly Mangalica pigs. Acta Alimentaria. 45(2):190-197.

http://dx.doi.org/10.1556/AAlim.2015.0007

Torres Filho R de A, Cazedey HP, Fontes P R, Ramos A de LS, Ramos EM. 2017. Drip loss assessment by different analytical methods and their relationships with pork quality classification. J Food Qual. 2017. https://doi.org/10.1155/2017/9170768

Triki $M$, Herrero AM, Jiménez-Colmenero F, RuizCapillas C. 2018. Quality assessment of fresh meat from several species based on free amino acid and biogenic amine contents during chilled storage. Foods 7:132. http://dx.doi.org/10.33 90/foods7090132

van Heerden SM, Morey L. 2014. Nutrient content of South African C2 beef offal. Food Measure 8:249-258. https://doi.org/10.1007/s11694-014-9198-z

Warner RD. 2017. The Eating Quality of Meat IV- Water-Holding Capacity and Juiciness. In Toldrá F (ed.), Lawrie's Meat Science. Duxford (UK): Woodhead Publishing. http://dx.doi.org/10.1016/ B978-0-08-100694-8.00005-4 